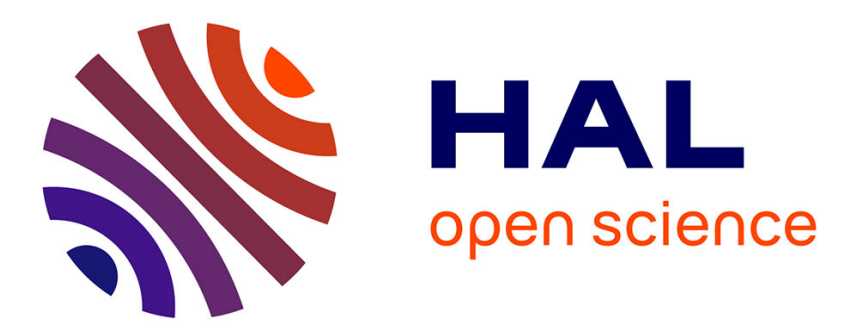

\title{
Early life ionizing radiation exposure and cancer risks: systematic review and meta-analysis
}

Kossi Abalo, Estelle Rage, Klervi Leuraud, David Richardson, Hubert Ducou Le Pointe, Dominique Laurier, Marie Odile Bernier

\section{- To cite this version:}

Kossi Abalo, Estelle Rage, Klervi Leuraud, David Richardson, Hubert Ducou Le Pointe, et al.. Early life ionizing radiation exposure and cancer risks: systematic review and meta-analysis. Pediatric Radiology, 2021, 51 (1), pp.45-56. 10.1007/s00247-020-04803-0 . hal-03110862

\section{HAL Id: hal-03110862 https://hal.science/hal-03110862}

Submitted on 14 Jan 2021

HAL is a multi-disciplinary open access archive for the deposit and dissemination of scientific research documents, whether they are published or not. The documents may come from teaching and research institutions in France or abroad, or from public or private research centers.
L'archive ouverte pluridisciplinaire HAL, est destinée au dépôt et à la diffusion de documents scientifiques de niveau recherche, publiés ou non, émanant des établissements d'enseignement et de recherche français ou étrangers, des laboratoires publics ou privés. 


\section{Pediatric Radiology \\ Early life ionizing radiation exposure and cancer risks: Systematic review and meta- analysis \\ --Manuscript Draft--}

\begin{tabular}{|c|c|}
\hline Manuscript Number: & PRAD-D-20-00027R2 \\
\hline Full Title: & $\begin{array}{l}\text { Early life ionizing radiation exposure and cancer risks: Systematic review and meta- } \\
\text { analysis }\end{array}$ \\
\hline Article Type: & Original Article \\
\hline \multicolumn{2}{|l|}{ Funding Information: } \\
\hline Abstract: & $\begin{array}{l}\text { Background: lonizing radiation use for medical diagnostic purposes has substantially } \\
\text { increased over the last three decades. Moderate to high doses of radiation are well } \\
\text { established causes of cancer, especially for exposure at young ages. However, cancer } \\
\text { risk from low-dose medical imaging is debated. } \\
\text { Objective: We aim to review the literature on cancer risks associated with prenatal and } \\
\text { postnatal medical diagnostic ionizing radiation exposure among children and to assess } \\
\text { this risk through a meta-analysis. } \\
\text { Methods: A literature search of five electronic databases supplemented by hand } \\
\text { search was performed to retrieve relevant epidemiological studies published from } 2000 \\
\text { to } 2019 \text {, including patients aged < } 22 \text { years exposed to medical imaging ionizing } \\
\text { radiation. Pooled Odds Ratio (OR pooled ) and pooled Excess Relative Risk (ERR } \\
\text { pooled) representing the excess of risk per unit of organ dose were estimated with a } \\
\text { random-effect model. } \\
\text { Results: Twenty-four studies were included. For prenatal exposure ( } X \text {-ray or computed } \\
\text { tomography (CT)), no significant increased risk for all-cancer, leukemia and brain } \\
\text { tumors were reported. For postnatal exposure, increased risks were observed only for } \\
\text { CTs, mostly for leukemia: ERR pooled }=26.9 \text { Gy }-1 \text { ( } 95 \% \text { confidence interval: } 2.7, \\
57.1 \text { ) and brain tumors: ERR pooled }=9.1 \text { Gy }-1 \text { ( } 95 \% \text { confidence interval: } 5.2,13.1 \text { ). } \\
\text { Conclusion: CT exposure in childhood appears to be associated with increased risks } \\
\text { of cancer while no significant association was observed with diagnostic X-rays. } \\
\text { Methodological limitations of the studies considered would be handled in upcoming } \\
\text { large international studies. Results support optimization efforts to minimize doses to } \\
\text { pediatric patients. } \\
\text { Keywords: prenatal, postnatal, low-dose ionizing radiation, cancer, CT }\end{array}$ \\
\hline Corresponding Author: & $\begin{array}{l}\text { Kossi Dovene ABALO } \\
\text { Institut de Radioprotection et de Surete Nucleaire } \\
\text { Fontenay aux Roses, Ile-de-France FRANCE }\end{array}$ \\
\hline \multicolumn{2}{|l|}{$\begin{array}{l}\text { Corresponding Author Secondary } \\
\text { Information: }\end{array}$} \\
\hline Corresponding Author's Institution: & Institut de Radioprotection et de Surete Nucleaire \\
\hline \multicolumn{2}{|l|}{$\begin{array}{l}\text { Corresponding Author's Secondary } \\
\text { Institution: }\end{array}$} \\
\hline First Author: & Kossi Dovene ABALO, MPH, MSc, PhD Student \\
\hline \multicolumn{2}{|l|}{ First Author Secondary Information: } \\
\hline \multirow[t]{7}{*}{ Order of Authors: } & Kossi Dovene ABALO, MPH, MSc, PhD Student \\
\hline & Estelle Rage, PharmD, PhD \\
\hline & Klervi Leuraud, PhD \\
\hline & David B Richardson, PhD \\
\hline & Hubert Ducou Le Pointe, MD, PhD \\
\hline & Dominique Laurier, PhD \\
\hline & Marie-Odile Bernier, MD, PhD \\
\hline
\end{tabular}


Order of Authors Secondary Information:

Author Comments:

I had some problems to perform the figures as requested in the editor's comment. To avoid figures to be pixeled, I provided in the submission, either the pdf format (in figures' party) and the TIFF format as supplemental material. Both the .PDF and .tiff format of the figures are the same and hope that one of these formats will fit the quality of resolution required. 
Original article

Early life ionizing radiation exposure and cancer risks: Systematic review and metaanalysis

Kossi D. Abalo ${ }^{1}$, Estelle Rage ${ }^{1}$, Klervi Leuraud ${ }^{1}$, David B. Richardson ${ }^{2}$, Hubert Ducou Le Pointe $^{3}$, Dominique Laurier ${ }^{1}$, Marie-Odile Bernier ${ }^{1}$

\section{Commented [1]:}

Please check the presentation of each author name for spelling and completeness. At least one first or middle name

must be complete. Please include initials for middle or first

names if not spelled out. Also, please check the metadata for

consistency. Note that this (the metadata) is how the author

names will appear in citation catalogues.

\section{$\square$ Kossi D. Abalo}

kossi.abalo@irsn.fr

${ }^{1}$ Laboratory of Epidemiology,

Institute for Radiological Protection and Nuclear Safety,

BP 17, 92262 Fontenay-aux-Roses, France

2 Department of Epidemiology,

School of Public Health, University of North Carolina,

Chapel Hill, NC, United States

${ }^{3}$ Department of Pediatric Imaging,

Hôpital d'Enfants Armand-Trousseau APHP,

Paris, France 


\begin{abstract}
Background The cancer risk from low-dose medical imaging is debated.

Objective To review the literature on cancer risks associated with prenatal and postnatal medical diagnostic ionizing radiation exposure among children and to assess this risk through a metaanalysis.
\end{abstract}

Materials and methods A literature search of five electronic databases supplemented by a hand search was performed to retrieve relevant epidemiological studies published from 2000 to 2019 , including patients younger than 22 years of age exposed to medical imaging ionizing radiation.

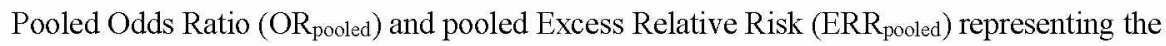
excess of risk per unit of organ dose were estimated with a random effect model.

Results Twenty-four studies were included. For prenatal exposure (radiographs or computed tomography $[\mathrm{CT}]$ ), no significant increased risk was reported for all cancers, leukemia and brain tumors. For postnatal exposure, increased risks were observed only for CTs, mostly for leukemia: $\mathrm{ERR}_{\text {pooled }}=26.9 \mathrm{~Gy}^{-1}(95 \%$ confidence interval [CI]: $2.7,57.1)$ and brain tumors: $\mathrm{ERR}_{\text {pooled }}=9.1$ $\mathrm{Gy}^{-1}(95 \% \mathrm{CI}: 5.2,13.1)$.

Conclusion CT exposure in childhood appears to be associated with increased risks of cancer while no significant association was observed with diagnostic radiographs.

Keywords Cancer, Children, Computed tomography, Ionizing radiation, Postnatal, Prenatal, Radiography, Risk 


\section{Introduction}

Medical diagnostic imaging using ionizing radiation is a very important tool in patients' care and substantial benefits arise from its use. Recent decades have been marked by an increased use of medical radiation imaging [1] representing an annual growth of about $5 \%$ to $8 \%$ per capita [2], mostly in developed countries.

Although single doses delivered per examination have decreased over the years, thanks to advances in technologies, protocols improvements, awareness and the reactivity of radiologists to improve their daily practice in accordance with scientific and medical recommendations, overall collective doses continue to increase [3-5], resulting from the growing number of tests performed and the use of procedures, such as computed tomography (CT), that are known to deliver much higher doses than conventional radiology procedures.

Several epidemiological studies of populations exposed to high to moderate doses of ionizing radiation have shown an increased risk of cancer [6-9]. Increased risk of cancer with decreasing age at exposure has been described $[2,10]$, hence foetuses and children are more radiosensitive [2].

Studies in the 1950s and 1960s linked prenatal and postnatal diagnostic X-ray exposure to an increased risk of childhood cancer [11-15]. However, with the decrease of doses observed over the years, the association became weak, especially for postnatal exposure [16].

Since former reviews of literature on children exposed to medical diagnostic radiation [9, 16-19] did not include recent cohorts on CT and interventional procedures, or quantitative 
summaries, we aimed to assess cancer risk subsequent to prenatal and postnatal medical diagnostic radiation exposure through a systematic review, and to provide a quantitative summary on the overall risk estimate.

\section{Materials and methods}

We followed the Preferred Reporting Items for Systematic Reviews and Meta-Analyze guidelines (PRISMA) [20] adapted to observational studies.

\section{Online searches}

An online-based literature search was conducted in July 2019 in PubMed, Scopus, Web of Science, Global Health and EMBASE. Specific keywords: ((neoplasms OR cancer) AND risk AND medical AND (diagnosis OR diagnostic) AND ("radiation exposure" OR (radiation AND exposure)) AND (child OR children)) were used. An additional search was carried out by hand through references from relevant publications and international reports such as BEIR VII [21] and UNSCEAR $2006 \& 2013$ [2,22].

All relevant articles fulfilling the selection criteria based (see below) on their title and abstract were selected and reviewed by two different authors (E.R. and K.D.A.), with a review by a third author (M.-O.B.) in case of discrepancy. Duplicate studies from the different databases 
were removed and studies providing completed quantitative information and risk estimate were then included in the meta-analysis.

\section{Selection criteria}

Eligible studies were cohort and case-control studies, published in English from Jan. 1, 2000, to July 31,2019 , involving children younger than 22 years at exposure. The exposure period was restricted to 1970 onward to ensure comparability with more recent practices since doses tend to decrease over time. Abstracts of congresses, meta-analyses, letters and authors' comments were ineligible but were checked to find any relevant reference. In case of publications on overlapping populations or updated publications [23-30], only data from the most complete study were considered $[25,27,28,30]$.

Methodological quality assessment of individual studies

To assess the risk of bias for individual studies, the Newcastle-Ottawa Scale (NOS) for quality assessment of non-randomized studies [31] and Agency for Healthcare Research and Quality (AHRQ) standards [32] for observational study were applied by two investigators (E.R. and K.D.A.). NOS quality tools uses eight items, grouped into three domains of potential bias such as selection (representation of the sample, sample size, non-respondents, ascertainment of the exposure), comparability (the subjects in different outcome groups are comparable, based on the 
study design or analysis, and confounding factors are controlled) and outcome/exposure (assessment of outcome or exposure and statistical test). A maximum of one star can be given for each item within the selection and outcome categories and a maximum of two stars can be given for comparability. To convert the NOS into AHRQ standards (good, fair and poor quality) thresholds are as follows:

- Good quality: 3 or 4 stars in selection domain AND 1 or 2 stars in comparability domain AND 2 or 3 stars in outcome/exposure domain.

- Fair quality: 2 stars in selection domain AND 1 or 2 stars in comparability domain AND 2 or 3 stars in outcome/exposure domain.

- Poor quality: 0 or 1 star in selection domain OR 0 star in comparability domain OR 0 or 1 star in outcome/exposure domain.

\section{Statistical analysis}

Studies providing a comprehensive risk estimate were set together to generate a summarized risk of cancer following medical diagnostic radiation exposure. In radiation epidemiology, however, the association between cancer risk and exposure is most often described by a risk difference or excess risk rather than a risk ratio or relative risk. In the case of an Excess Relative Risk (ERR) model, a linear multiplicative relationship between risk and exposure is assumed rather than an exponential relationship [21]. The ERR is the proportional increase in risk over the background rate of cancer (in the absence of exposure) per unit of dose, as follows: $R R=1+\beta D$, where 
RR is the relative risk, $\beta$ is the ERR and $D$ is the dose received. For example, a RR of 1.2 equals to an ERR of 0.2 , per unit of dose which corresponds to an increase in risk of $20 \%$ per unit of dose.

We estimated a pooled ERR to assess the strength of the association when provided from the individual studies otherwise a pooled relative risk (RR) or odds ratio (OR) is computed.

Analysis has been performed by period of exposure (pre- or postnatal) and type of cancer. The DerSimonian and Laird random-effect model was used to estimate the overall effect size [33] to account for within and between study heterogeneities. Confidence Intervals (CIs) bounds of ERRs commonly reported from epidemiological studies may be non-symmetric when estimated under different hypothesis with different methods (Wald test, maximum likelihood, profile likelihood). Inference of standard deviation from the ERR's CIs in such circumstance could lead to biased results. An alternative DerSimonian and Laird-based model proposed by Richardson et al. [34] was used to estimate the pooled effect of ERRs.

We assessed a study's small size effect and quantified the contribution of heterogeneity to the summarized estimate with the $I^{2}$ statistic, calculated as follows:

$$
I^{2}=1-\frac{d f}{Q}
$$

where $Q$ is the Cochran's statistic of heterogeneity, which follows a standard $\chi^{2}$ distribution with $d f=k-1$ degree of freedom ( $k$ is the number of individual studies).

$I^{2}$ is interpreted as the proportion of the total variation of the estimated effect due to heterogeneity between studies [33]. Publication and selection bias were assessed and tested using the Egger test $[35,36]$. Statistical significance was defined by $P<0.05$. 
All statistical analyses were conducted using Stata statistical software, STATA/MP 15.1

(Stata Corp, College Station, Texas, USA) and R 3.5.1 software.

\section{Results}

The systematic search yielded 1,674 articles. Figure 1 displays the flow diagram of selection of the relevant studies. After excluding duplicated studies $(n=181), 1,493$ articles have been screened and 254 eligible articles have been reviewed, with 24 included in the review according to prenatal (Table 1) [37-44] and postnatal radiation exposure (Tables 2 and 3) [25, 26, 29, 30, $37,38,41,43-55]$. There were 13 case-control studies $[26,37-41,43,44,52-56]$ and 11 cohort studies $[25,29,30,42,45-51]$ (Fig. 1).

Prenatal diagnostic radiation exposure

Cancer risks related to prenatal radiation exposure have been investigated in seven case-control studies [37-41, 43, 44] and in one cohort study [42] (Table 1). Medical examinations investigated were X-ray in five out of eight studies [37-40,43], and X-ray coupled with CT in two studies $[41,44]$. Intravenous pyelograms and radionuclide tests were evaluated in one study [41].

In the case-control studies, cancer cases were identified from cancer registries while controls were randomly selected from population registries and matched to cases on gender and 
age at cancer diagnosis. Additional matching criteria such as geographic region and residence were applied in several studies [37, 39-41,44]. Age at cancer diagnosis ranged from 0 to 16 years except in one study in which the diagnosis age ranged from 7 to 19 years [44]. Maternal exposure to radiation was ascertained by questionnaires or interviews reporting the type of examination, the trimester of pregnancy at the time of the examination and the body part examined. In three out of seven studies, questionnaires were completed by obstetrical records $[39,42,43]$.

No statistically significant increased risk of all cancer, leukemia or brain tumors, neither for X-ray nor CT exposure were reported in the eight studies considered. Since doses to the fetus were not estimated, no study was able to derive dose-response analyses.

Risk summaries were estimated for leukemia and brain tumors based on four $[38,39,41$, $43]$ and three studies $[37,43,44]$, respectively. The pooled analyses included, respectively, 6,274 cases and 12,426 controls for the leukemia subgroup and 3,461 cases and 7,924 controls for the brain tumors subgroup. Methodological quality scores of included studies were all satisfied, with NOS scores ranging from 6 to 9 (good quality according to AHRQ scores).

No increased risk for leukemia following prenatal exposure (any exposure versus no exposure) could be observed $\mathrm{OR}_{\text {pooled }}=1.08 ; 95 \%$ confidence interval (CI): 0.90, 1.28 (Fig. 2), with no reported heterogeneity between studies $I^{2}=23.2 \%, P=0.27$.

No increased risk of brain tumors was reported $\mathrm{OR}_{\text {pooled }}=0.93 ; 95 \% \mathrm{CI}: 0.68,1.28$ (Fig. 3) and no heterogeneity between studies was observed $I^{2}=0.0, P=0.72$.

No publication bias was idenitified by the Egger tests for leukemia $(P=0.52)$ and brain tumors $(P=0.49)$. 
Postnatal diagnostic radiation exposures

There were 21 studies $[25,26,29,30,37,38,41,43-56]$ on childhood radiation medical exposure (Tables 2 and 3). Beside X-ray and CT, which were the most frequently studied types of procedures, some specific examinations such as cardiac catheterization or cystography were also considered. CT exposure was mainly investigated in cohort studies whereas case-control studies predominantly explored X-ray exposure.

Subjects' exposures were identified from hospital records or from health insurance databases while cancer cases were retrieved from cancer registries $[25,27,30,41,44-47,49,56]$. In some CT studies with medical information available, children with cancer-predisposing factors $[25,28,46]$ and children subjected to CT because of suspected cancer $[30,56]$ were excluded from the analyses. To deal with reverse causality (cancers that were caused by the underlying medical conditions prompting the CT rather than by the dose delivered during the examination), various latency periods were applied, ranging from 3 to 24 months for lymphohematopoietic malignancies, and from 12 to 60 months for solid cancers. Age at inclusion, i.e. at first exposure, varied from 0 to 22 years, with some studies focusing only on children first exposed before the age of 10 years [28] or 15 years [25,49]. Mean follow-up extended from 4 years [49] to 8.5 years $[50]$.

Organ doses were estimated only for CT studies, based on patient characteristics (age, gender), type of examination and machine-specific settings retrieved from radiology protocols [28], published radiologic survey data $[30,45,49]$, or from the Picture Archiving and 
Communication System (PACS) [57]. The cumulative estimated doses ranged from 5.9 mGy to $10.1 \mathrm{mGy}$ to the red bone marrow and from $18.3 \mathrm{mGy}$ to $49 \mathrm{mGy}$ to the brain (Table 2 ).

X-ray exposure was not associated with increased risks of all cancers $[45,49,50]$, lymphohematopoietic malignancies or brain tumors $[37,43,44,52,54]$.

Exposure to cystourethrography procedures was statistically associated with increased risks of genital and urinary system cancers as well as hematological system malignancies [47]. Standardized incidence ratio (SIR) of all cancers (SIR 3.01, 95\% CI 2.09-4.19) and lymphoma (SIR 9.15, 95\% CI 5.66-13.97) were increased and significantly associated with childhood cardiac catheterization procedures [51] but were no more increased after censoring transplant recipients (SIR $0.90,95 \%$ CI $0.49,1.49$ for all cancers with 0 case for lymphoma).

CT studies reported significant increased risks for lymphohematopoeitic malignancies $[30,45,50]$ and for leukemia [56] when others found nonsignificant increased risks for leukemia $[41,49]$ by comparing children undergoing one or more CTs versus none. An almost twofold increase of risks of brain tumor have been reported $[45,46,50]$ (one or more CT versus none) while some studies have not shown any increased risk $[44,54]$ regardless of the region exposed.

Among the six CT studies providing organ doses $[28,30,45,49,50,56]$, pooled ERRs per Gy were calculated for leukemia and brain tumors. Overall, the pooled analysis included $11,398,728$ and $11,393,070$ subjects for leukemia and brain tumor risks analyses, respectively. Among them, 437 leukemias and 478 brain tumor cases were observed. The studies were comparable, and the methodological quality of the included studies wasgood, according to AHRQ, with NOS scores ranging from 7 to 9 . We observed a significant increased risk for leukemia $\mathrm{ERR}_{\text {pooled }}=26.9 \mathrm{~Gy}^{-1}$ 95\% CI: $2.7,57.1$ based on 6 studies $[28,30,45,49,50,56]$ (Fig. 4), which represents an increase of $2.69 \%$ per mGy of dose over the background risk of leukemia. 
There was moderate heterogeneity between studies $I^{2}=60.3 \%(P=0.03)$. Sensitivity analyses in which the pooled ERR was calculated excluding each study one at a time revealed no substantial alteration of the aggregate ERR except when excluding the Dutch study [50], which accounted for a large weight of the pooled analysis, leading to a higher pooled ERR after the exclusion of this study. Publication bias was suspected $(P=0.03)$ suggesting that small studies with negative results were less often published.

The pooled ERR for brain tumors was significantly increased $\mathrm{ERR}_{\text {pooled }}=9.1 \mathrm{~Gy}^{-1} 95 \% \mathrm{CI}$ : $5.2,13.1$ based on 5 studies $[28,30,45,49,50]$ (Fig. 5), which represents an increase of $0.91 \%$ per $m G y$ of dose over the background risk of brain tumors. Small heterogeneity between study was found $I^{2}=32 \%$ and no publication or selection bias was suspected $(P=0.16)$.

\section{Discussion}

Cancer risks after prenatal or postnatal medical diagnostic radiation exposure were analyzed based on 24 studies. Our review did not find any statistically increased risks of all cancers, leukemia and brain tumors after prenatal X-ray or CT exposures. For postnatal exposure, increased risks were observed for leukemia as well as brain tumors after CT exposure while no evidence of an increased risk of all cancers was observed after X-ray exposure.

Early published data in the 1950s, mainly the Oxford Survey of Childhood Cancers studies $[11,13,58]$ and other epidemiological studies $[59,60]$, reported an increased cancer risk related to prenatal X-ray exposure $[11,13]$. However, the following studies carried out a few 
years later did not show such a statistically significant association $[16,61,62]$. Nevertheless, the positive association, albeit non-statistically significant, between prenatal X-ray and leukemia $\left(\mathrm{OR}_{\text {pooled }} 1.08 ; 95 \% \mathrm{CI}: 0.90,1.28\right)$ is consistent with earlier much more statistically informative analyses that found results rejecting the null $[13,60]$.

A possible explanation for the difference between the cancer risk associated with prenatal irradiation estimated in this meta-analysis and estimated from previous studies may be linked to the decline in X-ray frequency during pregnancy by shifting to nonionizing procedures such as sonography or magnetic resonance imaging $[15,63]$ and the decrease in X-ray doses due to the setting and improvement of radiation protection rules for patients. Current $\mathrm{x}$-ray systems delivere fetal radiation doses of about $1.7 \mu \mathrm{Gy}$ for spine measurement and $2.7 \mu \mathrm{Gy}$ for femur measurement during the first trimester [65].

Little is known about the potential harm of CT exposure to the fetus. Because of higher doses delivered by CT compared to conventional radiology [63, 64], the increased use of CT during pregnancy $[65,66]$ for non-obstetrical conditions might be an issue. Only one study [42] focused specifically on the link between maternal CTs and a subsequent malignancy in the child and didn't observed any cancer risk in children (hazard ratio [HR] 0.68; 95\% CI: $0.25,1.80$ ) [42]. But a limit of this study is the lack of dosimetry assessment of the fetus exposure [42].

Postnatal diagnostic X-ray exposure has been the focus of numerous studies in the last half century. Early studies $[11,67,68]$ reported increased risks of leukemia in patients exposed to diagnostic X-ray compared to controls while more recent studies [69-71] did not report increased risks.

Because of the large increase in CT use over the years, several recent epidemiological studies have assessed the risk of cancer following CT exposure in childhood [28, 30, 45]. Among 
these studies, most reported increased risks of leukemia $[28,30,45]$ and brain tumors $[30,45$, 46], some of them without reaching significance [48]. In the present analysis, we reported a summarized excess relative risk of $\mathrm{ERR}_{\text {pooled }}=26.9 \mathrm{~Gy}^{-1}(95 \% \mathrm{CI}: 2.7-57.1)$ for leukemia and $\mathrm{ERR}_{\text {pooled }}=9.1 \mathrm{~Gy}^{-1}(95 \% \mathrm{CI}: 5.2-13.1)$ for brain tumors, indicating an increase in the risks of leukemia and brain tumors over the background risks of $2.69 \%$ and $0.91 \%$, respectively, per unit of mGy due to postnatal CT exposure based on linear dose-response models. That means, for a given $\mathrm{CT}$ delivering $10 \mathrm{mGy}$ to the red bone marrow (or to the brain), the leukemia (or brain tumor) risk increases by about $27 \%$ (or $9 \%$ for brain tumor risk) over the respective background risks, holding all other factors constant. The major limits encountered in the CT studies are indication and reverse causation bias, uncertainties in dose reconstruction and insufficient statistical power. Indication and reverse causation bias can be suspected respectively when cancer-predisposing factors or early symptoms of undetected cancer are the indication of the CT [72]. Thus, the apparent excess incidence of cancer is not linked to the CTs performed but to the underlying conditions or undetected cancer that motivate the indication of the CT. In most of studies on CT $[30,45,46]$, no information on the indication of the CT examination was available. Then, the association between CT and cancer risk might likely be overestimated in case of bias. Authors challenged reverse causation bias by applying several increasing lag periods (minimal latent time between the exposure and the cancer diagnosis) to exclude as much as possible CTs that could be performed after the cancer initiation but before the diagnosis of cancer. Because leukemia genesis is rather short and diagnosis is not assessed by CT examination, reverse causation bias is unlikely to obscure the leukemia dose response analysis. The similar values of ERR for leukemia (ERR=0.045 per $\mathrm{mGy}, 95 \%$ CI $0.016,0.188$ ) reported in the Life Span Study supports this hypothesis $[6,30,45]$. It is much more difficult to exclude such a bias for brain 
tumors as their development might take years, when several exams, especially CTs, could be performed to investigate the undetected condition.

Confounding bias linked to underlying conditions predisposing to cancer has been scarcely investigated $[23,28]$. Reanalysis of the previous published data [30] according to medical information available for $40 \%$ of the UK CT cohort showed a decrease of previously estimated ERRs of $15 \%$ for leukemia and $30 \%$ for brain tumors, albeit still significantly increased. In the French cohort [28], analysis restricted to the patients without predisposing factors to cancer ( $97 \%$ of the studied population) reported risk estimates in the same range as those obtained in the whole cohort, ruling out a potential bias linked to predisposing conditions to cancer. However, the rather small number of cases and the short duration of follow-up prevent from definitive conclusions.

Aside from CT, studies of other procedures such as fluoroscopy and cardiac catheterization were scarce. A study of adults with congenital heart defects reported significantly higher cancer risks associated with increasing numbers of diagnostic and treatment cardiac procedures [73]. Cancer risk associated with cardiac catheterization during childhood has been analyzed in three studies with divergent results $[51,74,75]$. The most recent study from the UK with individual dose reconstruction [51] reported no increase in all cancers after disregarding transplant patiens, whose condition might predispose to cancer. The study had relatively low statistical power to detect an association as only 11,270 children were included.

One of the major limits in the reviewed studies is the lack of precise dose assessment, especially in earlier studies. Although the doses might be quite easily estimated based on machine-specific parameters, this information was scarcely documented until recently. The 
assessment of X-ray exposure based on interviews or questionnaires in case-control studies may lead to a recall bias, unless confirmed by a review of medical records $[39,42,43]$.

One strength of our study is the ability to estimate pooled ERR thanks to the alternative random-effect method of Richardson et al. [34], which allows the derivation of estimates of variance of published ERRs in case of nonsymmetrical confidence intervals.

Assessing the quality of individual studies included in a systematic review is fundamental to interpreting the review. Quality assessment is challenging due to the methodological intricacies and its subjective nature. We used two recognized tools, NOS for quality assessment of non-randomized studies [31] and AHRQ standards [32]) to assess quality and methodological limits of included studies in a standardized manner, and we applied the Preferred Reporting Items for Systematic review and Meta-Analysis (PRISMA) recommendations [20] for the reporting of the study's results. However, we did not weigh the pooled estimates on quality criteria, as quality scores were in the same range of values (NOS scores 6 to 9, and good quality for AHRQ scores) for the studies considered in each analysis. We used a random effect model to calculate the pooled estimates, which allows for potential between- and within-study heterogeneities, even if the hypothesis of heterogeneity was rejected in most of our analyses. Publication bias linked to the absence of studies of small size with negative results seems not to be a major limitation of our analysis as demonstrated by statistical tests. Restricting the study period to published articles from 2000 to 2019 ruled out studies with exposure before the $1970 \mathrm{~s}$, for the purpose of insuring a certain homogeneity in the exposure scenario since a downturn in doses per X-ray exam have been reported and CT machines had been introduced after that period [15]. This prevented the inclusion of old studies with outdated exposure conditions and medical practices. 
An important common limitation is the lack of statistical power linked to the small expected risk, the rather low frequency of these procedures during pregnancy and childhood, and the short follow-up of recent studies. Hopefully, ongoing international studies will be able to assess, with greater statistical power, the risks associated with radiation-induced malignancies in medical exposures and to address some limits of previous published data.

In that way, the ongoing European collaborative project EPI-CT (Epidemiological study to quantify risks for pediatric computerized tomography and to optimize doses) pools nine national cohorts of children exposed to CT and provides individual organ doses taking into account uncertainties in dose assessment. With the inclusion of about 1 million patients, EPI-CT will provide statistically powerful estimates of cancer risk associated with CT exposure [76]. An extension of the follow-up of the main cohorts of EPI-CT is also planned in the international MEDIRAD project (Implications of Medical Low Dose Radiation Exposure) [77], which aims to enhance the scientific bases and clinical practice of radiation protection in the medical field. Another ongoing study, HARMONIC (Health effects of cardiac fluoroscopy and modern radiotherapy in paediatrics) [78] is partly devoted to assess the risk of radiation-related malignancies in children undergoing cardiac catheterizations.

\section{Conclusion}

Although prenatal medical radiation during the last 50 years appeared unlikely related to a subsequent later life risk of cancer, pooled results from studies on CT exposure during childhood showed greater risks for leukemia and brain tumors. Published studies present some 
methodological limitations. Although the benefits of prenatal and postnatal diagnostic radiation examinations outweigh the risks associated with the doses delivered by these procedures, the results of this analysis justify continued efforts to optimize doses to patients.

\section{Compliance with ethical standards}

\section{Conflicts of interest None}

\section{References}

1. Hall EJ, Brenner DJ (2008) Cancer risks from diagnostic radiology. Br J Radiol 81:362-378

2. United Nations Scientific Committee on the Effects of Atomic Radiation (2008) Effects of ionizing radiation: United Nations Scientific Committee on the Effects of Atomic Radiation-UNSCEAR 2006 report, volume 1-report to the general assembly, with scientific annexes A and B. United Nations Office at Vienna: United Nations

3. Linet MS, Slovis TL, Miller DL et al (2012) Cancer risks associated with external radiation from diagnostic imaging procedures. CA Cancer J Clin 62:75-100

4. Institut de Radioprotection et de Sûreté Nucléaire (IRSN) (2015) Exposition de la population française aux rayonnements ionisants. Fontenay-aux-Roses

5. Watson SJ, Jones AL, Oatway WB, Hughes SJ (2005) Ionising radiation exposure of the UK population: UK review. HPA-RPD-001. Health Protection Agency, Centre for Radiation, Chemical and Environmental Hazards, Chilton, Oxfordshire, UK

6. Preston DL, Kusumi S, Tomonaga M et al (1994) Cancer incidence in atomic bomb survivors. Part III: Leukemia, lymphoma and multiple myeloma, 1950-1987. Radiat Res 137:S68-S97

7. Folley JH, Borges W, Yamawaki T (1952) Incidence of leukemia in survivors of the atomic bomb in Hiroshima and Nagasaki, Japan. Am J Med 13:311-321

8. Ozasa K, Shimizu Y, Suyama A et al (2011) Studies of the mortality of atomic bomb survivors, Report 14, 1950-2003: An overview of cancer and noncancer diseases. Radiat Res 177:229-243 
9. Wakeford R (2013) The risk of childhood leukaemia following exposure to ionising radiation-a review. J Radiol Prot 33:1-25

10. Preston DL, Cullings $H$, Suyama $A$ et al (2008) Solid cancer incidence in atomic bomb survivors exposed in utero or as young children. J Natl Cancer Inst 100:428-436

11. Stewart A, Webb J, Hewitt D (1958) A survey of childhood malignancies. Br Med J 1:14951508

12. Wakeford R (2008) Childhood leukaemia following medical diagnostic exposure to ionizing radiation in utero or after birth. Radiat Prot Dosimetry 132:166-174

13. Giles D, Hewitt D, Stewart A, Webb J(1956) Malignant disease in childhood and diagnostic irradiation in utero. Lancet 271:447

14. MacMahon B (1962) Prenatal x-ray exposure and childhood cancer. J Natl Cancer Inst 28:1173-1191

15. Linet MS, Kim KP, Rajaraman P (2009) Children's exposure to diagnostic medical radiation and cancer risk: epidemiologic and dosimetric considerations. Pediatr Radiol 39:S4-26

16. Schulze-Rath R, Hammer GP, Blettner M (2008) Are pre-or postnatal diagnostic X-rays a risk factor for childhood cancer? A systematic review. Radiat Environ Biophys 47:301-312

17. Baysson H, Etard C, Brisse HJ, Bernier M-O (2012) [Diagnostic radiation exposure in children and cancer risk: Current knowledge and perspectives]

Archives de Pédiatrie 19:64-73

18. Baysson H, Journy N, Roué T et al(2016) [Exposure to CT scans in childhood and longterm cancer risk: A review of epidemiological studies

\}Bulletin du Cancer 103:190-198

19. Bernier M-O, Journy N, Baysson H et al (2015) Potential cancer risk associated with CT scans: Review of epidemiological studies and ongoing studies. Progress in Nuclear Energy 84:116-119

20. Liberati A, Altman DG, Tetzlaff J et al (2009) The PRISMA statement for reporting systematic reviews and meta-analyses of studies that evaluate health care interventions: explanation and elaboration. PLoS Med 6:e1000100

21. National Research Council (2006) Health risks from exposure to low levels of ionizing radiation: BEIR VII phase 2. National Academies Press

22. United Nations Scientific Committee on the Effects of Atomic Radiation (UNSCEAR) (2013) Sources, Effects and Risks of Ionizing Radiation. Volume II. Scientific Annex B: Effects of Radiation Exposure of Children. New York 
23. de Gonzalez AB, Salotti JA, McHugh K et ak (2016) Relationship between paediatric CT scans and subsequent risk of leukaemia and brain tumours: assessment of the impact of underlying conditions. Br J Cancer 114:388-394

24. Hammer GP, Seidenbusch MC, Schneider K et al (2009) A cohort study of childhood cancer incidence after postnatal diagnostic X-ray exposure. Radiat Res 171:504-512

25. Hammer GP, Seidenbusch MC, Regulla DF et al (2011) Childhood cancer risk from conventional radiographic examinations for selected referral criteria: results from a large cohort study. AJR Am J Roentgenol 197:217-223

26. Infante-Rivard C (2003) Diagnostic x rays, DNA repair genes and childhood acute lymphoblastic leukemia. Health Phys 85:60-64

27. Infante-Rivard C, Mathonnet G, Sinnett D (2000) Risk of childhood leukemia associated with diagnostic irradiation and polymorphisms in DNA repair genes. Environ Health Perspect 108:495-498

28. Journy N, Rehel J-L, Le Pointe HD et al (2015) Are the studies on cancer risk from CT scans biased by indication? Elements of answer from a large-scale cohort study in France. Br J Cancer 112:185-193

29. Journy N, Roué T, Cardis E et al (2016) Childhood CT scans and cancer risk: impact of predisposing factors for cancer on the risk estimates. J Radiol Prot 36:N1-N7

30. Pearce MS, Salotti JA, Little MP et al (2012) Radiation exposure from CT scans in childhood and subsequent risk of leukaemia and brain tumours: a retrospective cohort study. Lancet 380:499-505

31. Wells GA, Shea B, O'Connell D et al (2015) The Newcastle-Ottawa Scale (NOS) for assessing the quality of nonrandomized studies in meta-analyses. http://www.ohri.ca/programs/clinical_epidemiology/oxford.asp. Accessed 24 Nov 2018

32. Viswanathan M, Ansari MT, Berkman ND et al (2012) Assessing the risk of bias of individual studies in systematic reviews of health care interventions. In: Methods guide for effectiveness and comparative effectiveness reviews.

https://effectivehealthcare.ahrq.gov/sites/default/files/pdf/methods-guidance-biasindividual-studies_methods.pdf $A c c e s s e d$

33. Sterne JA (2009) Meta-analysis in Stata: an updated collection from the Stata Journal. StataCorp LP

34. Richardson DB, Abalo K, Bernier M-O et al (2020) Meta-analysis of published excess relative rate estimates. Radiat Environ Biophys. doi: 10.1007/s00411-020-00863-w

35. Egger M, Davey Smith G, Schneider M, Minder C (1997) Bias in meta-analysis detected by a simple, graphical test. BMJ 315:629-634 
36. Steichen T (1998) Tests for publication bias in meta-analysis. Stata Technical Bulletin 7:

37. Schüz J, Kaletsch U, Kaatsch P et al (2001) Risk factors for pediatric tumors of the central nervous system: Results from a German population-based case-control study. Med Pediatr Oncol 36:274-282

38. Shu XO, Potter JD, Linet MS et al (2002) Diagnostic X-Rays and Ultrasound Exposure and Risk of Childhood Acute Lymphoblastic Leukemia by Immunophenotype. Cancer Epidemiol Biomarkers Prev 11:177-185

39. Roman E, Simpson J, Ansell P et al (2005) Perinatal and reproductive factors: a report on haematological malignancies from the UKCCS. Eur J Cancer 41:749-759

40. Goel R, Olshan AF, Ross JA et al (2009) Maternal exposure to medical radiation and Wilms tumor in the offspring: a report from the Children's Oncology Group. Cancer Causes Control 20:957-963

41. Bailey HD, Armstrong BK, de Klerk NH et al (2010) Exposure to diagnostic radiological procedures and the risk of childhood acute lymphoblastic leukemia. Cancer Epidemiol Biomarkers Prev 19:2897-2909

42. Ray JG, Schull MJ, Urquia ML et al (2010) Major radiodiagnostic imaging in pregnancy and the risk of childhood malignancy: a population-based cohort study in Ontario. PLoS Med 7:e1000337

43. Rajaraman $P$, Simpson J, Neta G et al (2011) Early life exposure to diagnostic radiation and ultrasound scans and risk of childhood cancer: case-control study. BMJ 342:d472

44. Tettamanti G, Shu X, Adel Fahmideh M et al (2017) Prenatal and postnatal medical conditions and the risk of brain tumors in children and adolescents: an international multicenter case-control study. Cancer Epidemiol Biomarkers Prev 26:110-115

45. Mathews JD, Forsythe AV, Brady Z et al (2013) Cancer risk in 680000 people exposed to computed tomography scans in childhood or adolescence: data linkage study of 11 million Australians. BMJ 346:12360

46. Huang W-Y, Muo C-H, Lin C-Y et al (2014) Paediatric head CT scan and subsequent risk of malignancy and benign brain tumour: a nation-wide population-based cohort study. $\mathrm{Br} \mathrm{J}$ Cancer 110:2354-2360

47. Liao $\mathrm{Y}-\mathrm{H}, \mathrm{Lin} \mathrm{C}-\mathrm{L}$, Wei C-C et al (2014) Subsequent cancer risk of children receiving post voiding cystourethrography: A nationwide population-based retrospective cohort study. Pediatric Nephrol 29:885-891

48. White IK, Shaikh KA, Moore RJ et al (2014) Risk of radiation-induced malignancies from CT scanning in children who underwent shunt treatment before 6 years of age: a retrospective cohort study with a minimum 10-year follow-up. J Neurosurg Pediatri 13:514519

\section{Commented [3]:}

Please complete reference 36 
49. Krille L, Dreger S, Schindel R et al (2015) Risk of cancer incidence before the age of 15 years after exposure to ionising radiation from computed tomography: results from a German cohort study. Radiat Environ Biophys 54:1-12

50. Meulepas JM, Ronckers CM, Smets AMJB et al (2018) Radiation exposure from pediatric CT scans and subsequent cancer risk in the Netherlands. J Nal Cancer Inst 111:256-263

51. Harbron RW, Chapple C-L, O'Sullivan JJ et al (2018) Cancer incidence among children and young adults who have undergone $\mathrm{x}$-ray guided cardiac catheterization procedures. Eur $\mathrm{J}$ Epidemiol 33:393-401

52. Mellemkjær L, Hasle H, Gridley G et al (2006) Risk of cancer in children with the diagnosis immaturity at birth. Paediatr Perinat Epidemiol 20:231-237

53. Khan S, Evans AA, Rorke-Adams L et al (2010) Head injury, diagnostic X-rays, and risk of medulloblastoma and primitive neuroectodermal tumor: a Children's Oncology Group study. Cancer Causes Control 21:1017-1023

54. Milne E, Greenop KR, Fritschi L et al (2014) Childhood and parental diagnostic radiological procedures and risk of childhood brain tumors. Cancer Causes Control 25:375383

55. Shih T-Y, Wu J, Muo C-S, Kao C-H (2014) Association between leukaemia and X-ray in children: A nationwide study. J Paediatr Child Health 50:615-618

56. Nikkilä A, Raitanen J, Lohi O, Auvinen A (2018) Radiation exposure from computerized tomography and risk of childhood leukemia: Finnish register-based case-control study of childhood leukemia (FRECCLE). Haematologica 103:1873-1880

57. Lee C, Kim KP, Bolch WE et al (2015) NCICT: a computational solution to estimate organ doses for pediatric and adult patients undergoing CT scans. J Radiol Prot 35:891-909

58. Bithell JF, Stewart AM (1975) Pre-natal irradiation and childhood malignancy: a review of British data from the Oxford Survey. Br J Cancer 31:271-287

59. Bithell JF, Stiller CA (1988) A new calculation of the carcinogenic risk of obstetric Xraying. Stat Med 7:857-864

60. Doll R, Wakeford R (1997) Risk of childhood cancer from fetal irradiation. Br J Radiol 70:130-139

61. Rodvall Y, Pershagen G, Hrubec Z et al (1990) Prenatal X-ray exposure and childhood cancer in Swedish twins. Int J Cancer 46:362-365

62. Inskip PD, Harvey EB, Boice JD Jr et al (1991) Incidence of childhood cancer in twins. Cancer Causes Control 2:315-324 
63. Børretzen I, Lysdahl KB, Olerud HM (2007) Diagnostic radiology in Norway-trends in examination frequency and collective effective dose. Radiat Prot Dosimetry 124:339-347

64. Mettler FA Jr, Bhargavan M, Faulkner K et al (2009) Radiologic and nuclear medicine studies in the United States and worldwide: frequency, radiation dose, and comparison with other radiation sources-1950-2007. Radiology 253:520-531

65. Chen MM, Coakley FV, Kaimal A, Laros RK Jr (2008) Guidelines for computed tomography and magnetic resonance imaging use during pregnancy and lactation. Obstet Gynecol 112:333-340

66. Righini M, Robert-Ebadi $\mathrm{H}$, Elias A et al (2018) Diagnosis of pulmonary embolism during pregnancy: a multicenter prospective management outcome study. Ann Intern Med 169:766773

67. Graham S, Levin ML, Lilienfeld AM et al (1966) Preconception, intrauterine, and postnatal irradiation as related to leukemia. Natl Cancer Inst Monogr 19:347-371

68. Polhemus DW, Koch R (1959) Leukemia and medical radiation. Pediatrics 23:453-461

69. Ager EA, Schuman LM, Wallace HM et al (1965) An epidemiological study of childhood leukemia. J Chronic Dis 18:113-132

70. Shu XO, Gao YT, Brinton LA et al (1988) A population-based case-control study of childhood leukemia in Shanghai. Cancer 62:635-644

71. Hartley AL, Birch JM, McKinney PA et al (1988) The Inter-Regional Epidemiological Study of Childhood Cancer (IRESCC): past medical history in children with cancer. J Epidemiol Community Health 42:235-242

72. Boice JD Jr (2015) Radiation epidemiology and recent paediatric computed tomography studies. Anna ICRP 44:236-248

73. Cohen S, Liu A, Gurvitz M et al (2018) Exposure to low-dose ionizing radiation from cardiac procedures and malignancy risk in adults with congenital heart disease. Circulation $137: 1334-1345$

74. McLaughlin JR, Kreiger N, Sloan MP et al (1993) An historical cohort study of cardiac catheterization during childhood and the risk of cancer. Int J Epidemiol 22:584-591

75. Modan B, Keinan L, Blumstein T, Sadetzki S (2000) Cancer following cardiac catheterization in childhood. Int J Epidemiol 29:424-428

76. Bernier M-O, Baysson H, Pearce MS et al (2018) Cohort Profile: the EPI-CT study: a European pooled epidemiological study to quantify the risk of radiation-induced cancer from paediatric CT. IntJ Epidemiol 48:379-381g

77. Home /MEDIRAD. http://www.medirad-project.ew/. Accessed 11 Mar 2020 
78. HARMONIC. In: ISGlobal. https://www.isglobal.org/en/-/harmonic. Accessed 11 Mar 2020 
Fig. 1 Preferred Reporting Items for Systematic Reviews and Meta-Analyses flow diagram of search, selection and inclusion of relevant studies

Fig. 2 Odds ratio (OR) of leukemia risk following prenatal medical diagnostic X-ray exposure Commented [4]: We need et al. added after every author in the graphic ORpooled pooled odds ratio

Fig. 3 Odds ratio (OR) of brain tumors risk following prenatal medical diagnostic X-ray exposure Commented [5]: We need et al added to each author in the graphic ORpooled pooled odds ratio

Fig. 4 Excess relative risk (ERR) of leukemia following postnatal medical diagnostic exposure to computed tomography scan

ERRpooled pooled excess relative risk

Fig. 5:Excess relative risk (ERR) of brain tumors following postnatal medical diagnostic exposure to computed tomography scan Commented [7]:

We need et al added to each author name in the graphic

ERRpooled pooled excess relative risk 
Table 1 Studies on prenatal medical ionizing radiation exposure and cancer risk

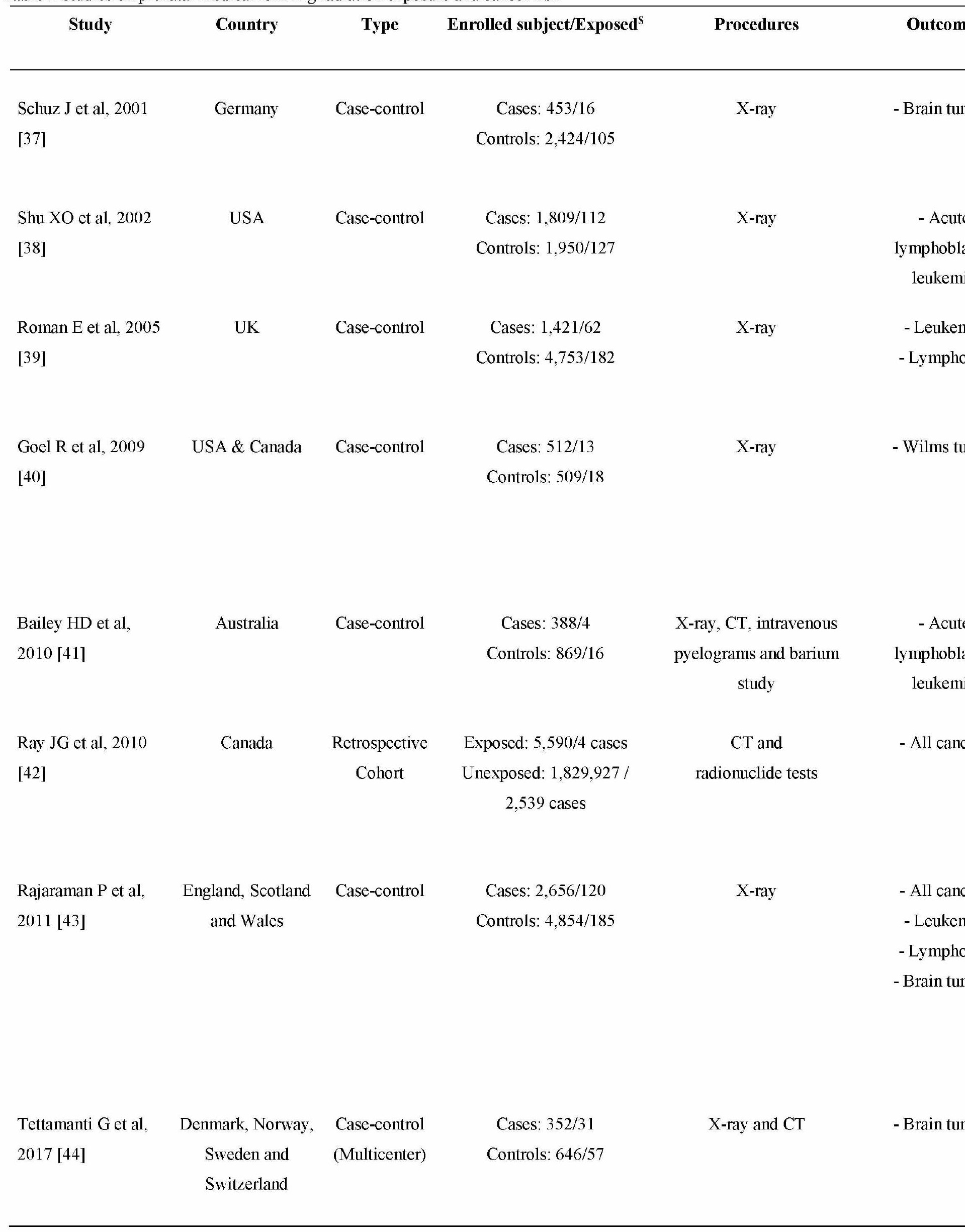


$\$$ Value reported in the "Enrolled subject/Exposed" column is that for all cancer combined or that for the given cancer reported; $\S$ adjus adjusted on at least age, gender and geographic area); * first trimester of pregnancy, ** second trimester of pregnancy, ***: third trimes tomography, $H R$ hazard ratio, OR odds ratio. Ray JG et al. 2010 [42]: 4 cases among 5.590 exposed subjects and 2.539 cases among 1.8 
Table 2 Cohort studies on postnatal medical ionizing radiation exposure and cancer risk

\begin{tabular}{|c|c|c|c|c|c|}
\hline Study & Enrolled subject/cases & $\begin{array}{l}\text { Period of } \\
\text { inclusion }\end{array}$ & $\begin{array}{c}\text { Age at } \\
\text { inclusion } \\
\text { (years) }\end{array}$ & Procedures & Outcomes \\
\hline
\end{tabular}

\begin{tabular}{|c|c|c|c|c|c|c|}
\hline $\begin{array}{l}\text { Hammer GP et al, } \\
2011[25], \\
\text { Germany }\end{array}$ & $78,527 / 68$ & $1976-2003$ & $<14.5$ & X-ray & $\begin{array}{l}\text { - All cancer } \\
\text { - Leukemia and lymphoma }\end{array}$ & - \\
\hline $\begin{array}{l}\text { Pearce MS et al, } \\
2012[30], \text { UK }\end{array}$ & $\begin{array}{c}178,604 / 74 \\
176,587 / 135\end{array}$ & $\begin{array}{l}1985-2002 \\
1986-2002\end{array}$ & $\begin{array}{l}0-22 \\
0-22\end{array}$ & $\mathrm{CT}$ & $\begin{array}{l}\text { - Leukemia } \\
\text { - Brain tumors }\end{array}$ & $\begin{array}{l}\text { RBM: } 2.32 \\
\text { Brain: } 0.25\end{array}$ \\
\hline $\begin{array}{l}\text { Mathews JD et al, } \\
2013 \text { [45], } \\
\text { Australia }\end{array}$ & $\begin{array}{c}\text { Exposed: } 680,211 / 3,150 \\
\text { Unexposed: } \\
10,261,420 / 57,524\end{array}$ & $1985-2005$ & $0-19$ & $\mathrm{CT}$ & $\begin{array}{l}\text { - All cancer* } \\
\text { - Lymphoma and } \\
\text { hematopoietic } \\
\text { - Brain tumors }\end{array}$ & $\begin{array}{l}\text { RBM: } 5.9^{n} \\
\text { Brain: } 49^{m}\end{array}$ \\
\hline $\begin{array}{l}\text { Huang WY et al, } \\
2014 \text { [46], Taiwan }\end{array}$ & $\begin{array}{c}\text { Exposed: } 24,418 / 39 \\
\text { Unexposed: } 97,668 / 122\end{array}$ & $1998-2006$ & $<18$ & $\mathrm{CT}$ & $\begin{array}{l}\text { - All-cancer } \\
\text { - Leukemia } \\
\text { - Brain tumors }\end{array}$ & - \\
\hline $\begin{array}{l}\text { Liao YH et al, } \\
2014 \text { [47], Taiwan }\end{array}$ & $\begin{array}{c}\text { Exposed: } 31,908 / 52 \\
\text { Unexposed: } 127,632 / 99\end{array}$ & $1997-2008$ & $1-18$ & $\begin{array}{l}\text { Cystourethro } \\
\text { graphy }\end{array}$ & $\begin{array}{l}\text { - Genital cancer } \\
\text { - Urinary system cancer } \\
\text { - Hematologic system }\end{array}$ & - \\
\hline $\begin{array}{l}\text { White IK et al, } \\
2014 \text { [48], USA }\end{array}$ & $104 / 0$ & 1991-2001 & $0-6$ years & CT & $\begin{array}{l}\text { - All cancer } \\
\text { - Leukemia } \\
\text { - Brain tumors }\end{array}$ & - \\
\hline $\begin{array}{l}\text { Krille L et al, } 2015 \\
\text { [49] } \\
\text { Germany }\end{array}$ & $39,184 / 38$ & $1980-2010$ & $<15$ & $\mathrm{CT}$ & $\begin{array}{l}\text { - All-cancer } \\
\text { - Leukemia } \\
\text { - Brain tumors }\end{array}$ & $\begin{array}{l}\text { RBM: } 11.7 \\
\text { Brain: } 34.4\end{array}$ \\
\hline $\begin{array}{l}\text { Journy N et al, } \\
2016 \text { [28], France }\end{array}$ & $67,274 / 106$ & $2000-2010$ & $<10$ & $\mathrm{CT}$ & $\begin{array}{l}\text { - Leukemia } \\
\text { - Lymphoma } \\
\text { - Brain tumors }\end{array}$ & $\begin{array}{l}\text { RBM: } 8.9 \\
\text { Brain: } 23.1\end{array}$ \\
\hline $\begin{array}{l}\text { Meulepas JM et al, } \\
2018[50] \\
\text { The Netherlands }\end{array}$ & $168,394 / 454$ & $1979-2012$ & $<18$ & $\mathrm{CT}$ & $\begin{array}{l}\text { - Leukemia } \\
\text { - Brain tumors }\end{array}$ & $\begin{array}{l}\text { RBM: } 9.5 \\
\text { Brain: } 38.5 \\
49.4)^{m(T Q R)}\end{array}$ \\
\hline $\begin{array}{l}\text { Harbron RW, } \\
2018[51] \\
\text { UK }\end{array}$ & $11,270 / 41$ & - & $<22$ & $\begin{array}{l}\text { Cardiac } \\
\text { catheterizatio } \\
\mathrm{n} \text { and } \mathrm{CT}\end{array}$ & $\begin{array}{l}\text { - Lymphohaematopoietic } \\
\text { neoplasia }\end{array}$ & RBM: 8.8 \\
\hline
\end{tabular}


Exclusion period: * 1 year, ** 2 years, $* * * 5$ years. $\uparrow$ per $100 \mathrm{mSv}, \S$ ERR for the whole population, $\$$ ERR after exclusion of patients with transplant, $95 \%$ CI $95 \%$ confidence interval, CT computed tomography, $h$ hazard ratio, IQR interquartile range, $m$ mean, $R B M$ red bone marrow; $s$ standardized incidence ratio, 
sd standard deviation Table 3 Case control studies on postnatal medical ionizing radiation exposure and cancer risk

\begin{tabular}{|c|c|c|c|c|c|c|c|}
\hline Study & $\begin{array}{c}\text { Enrolled } \\
\text { subject/exposed }\end{array}$ & $\begin{array}{l}\text { Period of } \\
\text { diagnosis }\end{array}$ & $\begin{array}{l}\text { Age at } \\
\text { diagnosi } \\
\text { s (years) }\end{array}$ & $\begin{array}{l}\text { Procedur } \\
\text { es }\end{array}$ & Outcomes & & $\begin{array}{l}\text { Risk estimate } \\
\text { (adjusted) } \\
\text { (95\% CI) }\end{array}$ \\
\hline $\begin{array}{l}\text { Schuz J et al, } \\
2001[37] \text {, } \\
\text { Germany }\end{array}$ & $\begin{array}{c}\text { Cases: } 458 / 142 \\
\text { Controls: } \\
2,425 / 818\end{array}$ & 1988-1993 & $<15$ & X-ray & - Brain tumors & OR & $\begin{array}{l}0.73(0.57- \\
0.94)\end{array}$ \\
\hline $\begin{array}{l}\text { Shu XO et al, } \\
2002 \text { [38], USA }\end{array}$ & $\begin{array}{c}\text { Cases: } 1,842 / 939 \\
\text { Controls: } \\
1,986 / 775\end{array}$ & $1989-1993$ & $<15$ & X-ray & $\begin{array}{l}\text { - Acute } \\
\text { lymphoblastic } \\
\text { leukemia }\end{array}$ & OR & $1.1(0.9-1.2)$ \\
\hline $\begin{array}{l}\text { Infante-Rivard } \\
\text { C, } 2003[26], \\
\text { Canada }\end{array}$ & $\begin{array}{c}\text { Cases: } 682 / 301 \\
\text { Controls: } \\
690 / 262\end{array}$ & $1980-1993$ & $<14$ & $\begin{array}{r}X-\text { ray }^{\$} \\
1 \\
>=2\end{array}$ & $\begin{array}{l}\text { - Acute } \\
\text { lymphoblastic } \\
\text { leukemia }\end{array}$ & OR & $\begin{array}{l}1.16(0.87- \\
1.55) \\
1.48(1.11- \\
1.97)\end{array}$ \\
\hline $\begin{array}{l}\text { Mellemkjaer L et } \\
\text { al, } 2006 \text { [52], } \\
\text { Denmark }\end{array}$ & $\begin{array}{c}\text { Cases: } 25 / 11 \\
\text { Controls: } 50 / 15\end{array}$ & 1977-1989 & $\begin{array}{c}\text { Newbor } \\
\text { ns }\end{array}$ & X-ray & - Brain tumors & OR & $2.2(0.6-8.8)$ \\
\hline $\begin{array}{l}\text { Bailey HD et al, } \\
2010 \text { [41], } \\
\text { Australia }\end{array}$ & $\begin{array}{c}\text { Cases: } 360 / 156 \\
\text { Controls: } \\
834 / 326\end{array}$ & 2003-2006 & $<14$ & $\begin{array}{l}\text { - X-ray } \\
\text { - CT }\end{array}$ & $\begin{array}{l}\text { - Acute } \\
\text { lymphoblastic } \\
\text { leukemia }\end{array}$ & OR & $\begin{array}{l}1.15 \\
(0.881 .52) \\
0.87(0.32- \\
2.34)\end{array}$ \\
\hline $\begin{array}{l}\text { Khan S et al, } \\
2010 \text { [53], USA }\end{array}$ & $\begin{array}{c}\text { Cases: } 299 / 15 \\
\text { Controls: } 299 / 12\end{array}$ & 1991-1997 & $<6$ & $\begin{array}{l}\text { Head X- } \\
\operatorname{ray}^{\S}\end{array}$ & $\begin{array}{c}\text { Medulloblastoma and } \\
\text { primitive } \\
\text { neuroectodermal } \\
\text { tumor (PNET) }\end{array}$ & OR & $1.3(0.49-3.7)$ \\
\hline $\begin{array}{l}\text { Rajaraman P et } \\
\text { al, } 2011[43], \\
\text { England, } \\
\text { Scotland and } \\
\text { Wales }\end{array}$ & $\begin{array}{c}\text { Cases: } 2,656 / 50 \\
\text { Controls: } 4,854 \\
\quad / 75\end{array}$ & 1992-1996 & $1-5$ & X-ray & $\begin{array}{l}\text { - All cancers } \\
\text { - Leukemia } \\
\text { - Lymphoma } \\
\text { - Brain tumors }\end{array}$ & OR & $\begin{array}{l}1.19(0.82- \\
1.74) \\
1.35(0.81- \\
2.27) \\
5.14(1.27- \\
20.8) \\
0.94(0.31- \\
2.92)\end{array}$ \\
\hline $\begin{array}{l}\text { Milne E et al, } \\
2014[54] \\
\text { Australia }\end{array}$ & $\begin{array}{c}\text { Cases: } 306 / 102 \\
\text { Controls: } \\
950 / 375\end{array}$ & $2005-2010$ & $<14$ & $\begin{array}{c}\text { - All } \\
\text { procedure } \\
s^{\mathcal{L}} \\
\text { - X-ray } \\
\text { - CT }\end{array}$ & - Brain tumors & OR & $\begin{array}{l}0.66(0.48- \\
0.90) \\
0.68(0.49- \\
0.93) \\
0.78(0.38- \\
1.59)\end{array}$ \\
\hline $\begin{array}{l}\text { Shih T-Y et al, } \\
2014 \text { [55], } \\
\text { Taiwan }\end{array}$ & $\begin{array}{c}\text { Cases: } 58 / 34 \\
\text { Controls: } 232 / 95\end{array}$ & $1998-2010$ & $6-18$ & X-ray & - Leukemia & OR & $\begin{array}{l}2.14(1.18- \\
3.87)\end{array}$ \\
\hline $\begin{array}{l}\text { Tettamanti G et } \\
\text { al, } 2017 \text { [44], } \\
\text { Denmark, } \\
\text { Norway, Sweden } \\
\text { and Switzerland }\end{array}$ & $\begin{array}{c}\text { Cases: } 352 / 159 \\
\text { Controls: } \\
646 / 333\end{array}$ & 2004-2008 & $7-9$ & $\begin{array}{l}\text { X-ray and } \\
\text { CT }\end{array}$ & - Brain tumors & $\underset{*}{\mathrm{OR}}$ & $\begin{array}{l}0.76(0.58- \\
1.01)\end{array}$ \\
\hline $\begin{array}{l}\text { Nikkila A et al, } \\
2018 \text { [56], } \\
\text { Finland }\end{array}$ & $\begin{array}{c}\text { Cases: } 911 / 8 \\
\text { Controls: } 2,730 / 9\end{array}$ & $1990-2011$ & $<15$ & $\mathrm{CT}$ & Leukemia & $\begin{array}{c}\text { OR } \\
\mathrm{EO} \\
\mathrm{R}\end{array}$ & $\begin{array}{l}2.82(1.05- \\
7.56) \\
13(2-26)^{\alpha}\end{array}$ \\
\hline
\end{tabular}


All estimated risks taking into account the latency period presented in the table.

95\% CI 95\% confidence interval, * non-adjusted OR, $\S$ only head X-ray not due to head injury, \$X-ray excluding dental procedures, $£$ all procedures, including dental procedures

$C T$ computed tomography, EOR excess odds ratio per $100 \mathrm{mGy}, I Q R$ interquartile range, OR odds Rratio; $R B M$ red bone marrow $\alpha$ : Nikkila A et al, 2018 [56] : leukemia excess odds ratio (EOR) 13 (95\% CI 2-26) per 100mGy, RBM (median+IQR): 10.1 (4.79-13.6) in the exposed group and RBM (median+IQR): $6.29(5.69-7.14)$ in controls. 


\section{All searches: 1,674}

PubMed: 318; Scopus: 199;

Web of Science: 399; Embase: 626;

Global health: 45 ; other sources: 87

Duplicates: 181

Screened out on title and abstract:

1,493

Selected for more detailed

information: 254

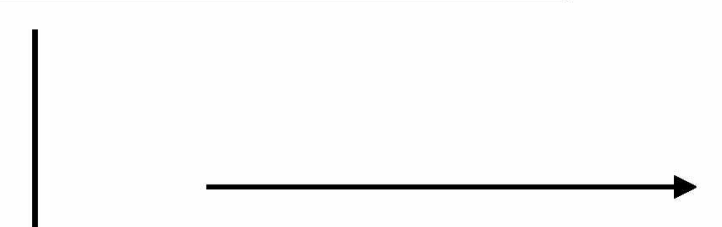

Title and abstract non-conform or noneligible: 1,239

Exclusion criteria: 230

- Environmental or high dose exposure: 21

- Dosimetry assessments: 27

- Lifetime attributable risk and mathematical modeling: 22

- Therapeutic procedures: 15

Relevant studies: 24

- Lack of quantitative data, case series or case reports: 13

- Others: 132

- $\quad 5$ studies treated both prenatal and postnatal exposures 


\section{Rajaraman P [43]}

Bailey HD [41]

Shu XO [38]

7

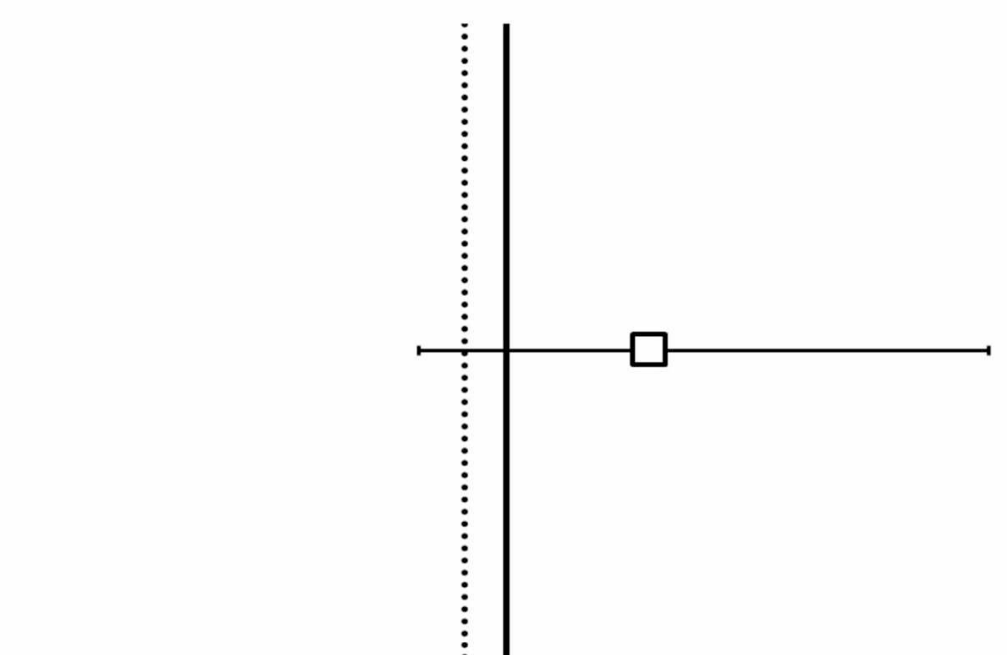

Roman E [39]

ORpooled

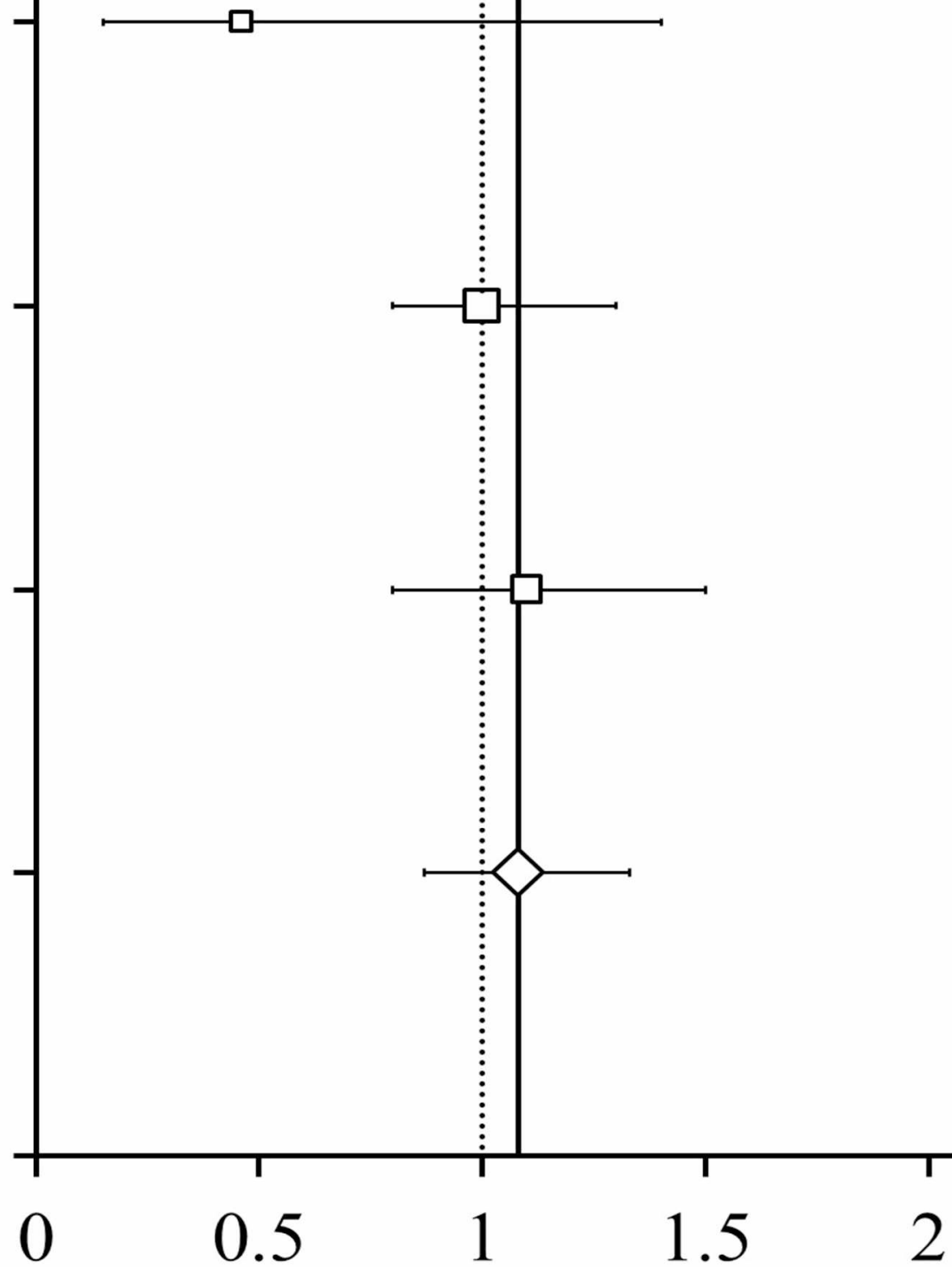

2 


\title{
Rajaraman P [43]
}

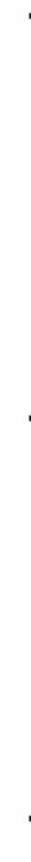

\author{
Tettamanti G [44]
}

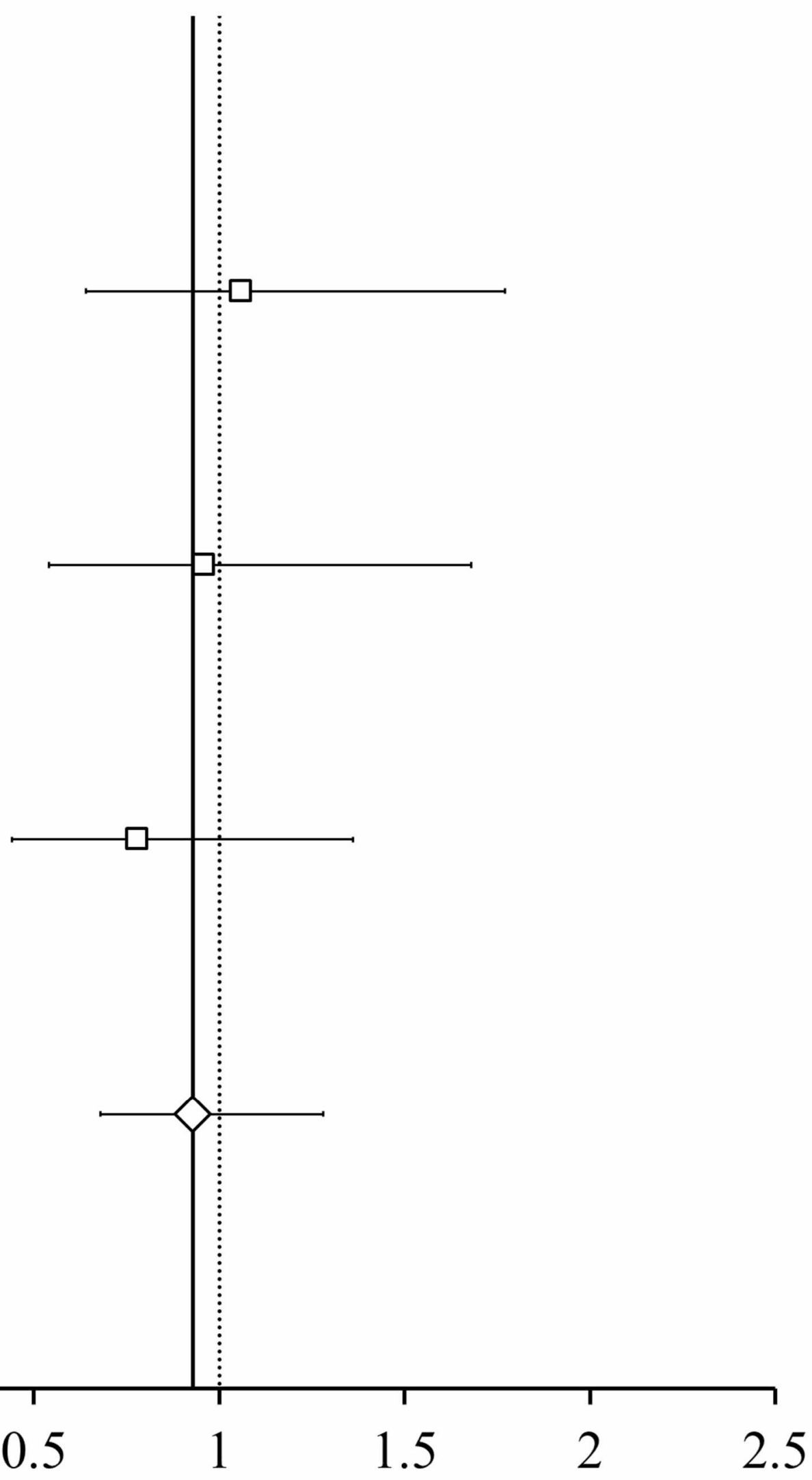

OR

Schuz J [37]

ORpooled

$0 \quad 0.5$

1.5

2

2.5 


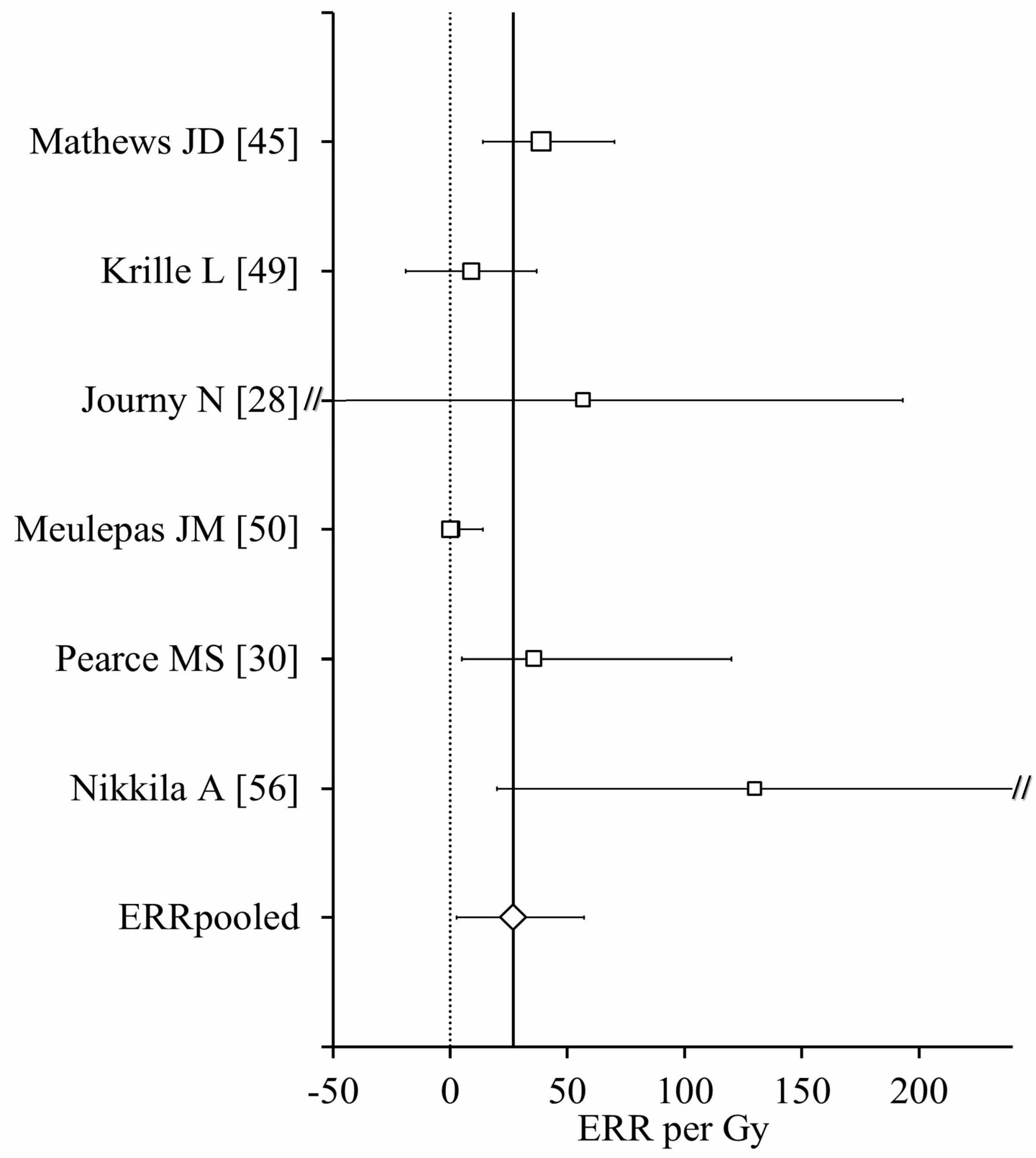


(Figure as TIFF object) Figure 1: Preferred Reporting Items for
Systematic Reviews and Meta-Analyses flow diagram of search,

Click here to access/download
Supplementary Material

Click here to access/download
Supplementary Material

\title{
Fig 1.tif

$$
\text { (n) }
$$

\begin{abstract}
Systematic Reviews and Meta-Analyses flow diagram of search,
\end{abstract}


(Figure as TIFF object) Figure 2: Odds ratio (OR) of leukemia risk following prenatal medical diagnostic $X$-ray exposure

\author{
Fig 2.7 .
}

\author{
(n)
}

\title{
Click here to access/download Supplementary Material Fig 2.TIF
}

Thas

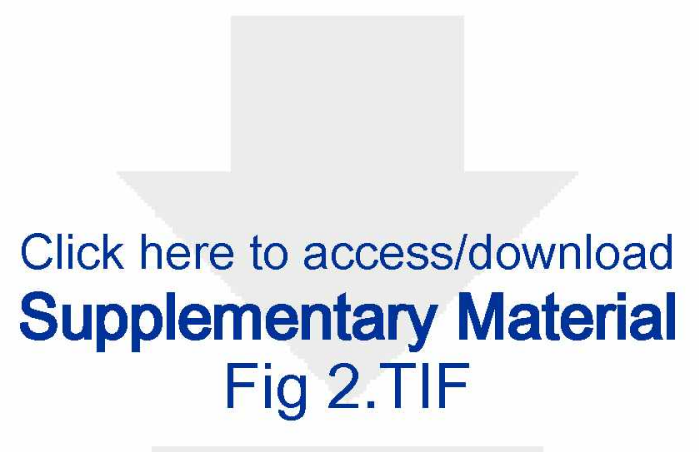

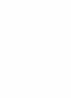

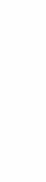

(n)


(Figure as TIFF object) Figure 3: Odds ratio (OR) of brain tumors risk following prenatal medical diagnostic $X$-ray exposure

Click here to access/download Supplementary Material

\section{Fig 3.TIF$$
\text { raras }
$$ 

leukemia risk following postnatal medical diagnostic exposure to

Click here to access/download Supplementary Material Fig 4.TIF 
(Figure as TIFF object) Figure 5: Excess relative risk (ERR) of
brain tumors risk following postnatal medical diagnostic exposure

Click here to access/download

Supplementary Material

Fig 5.TIF 
Click here to access/download Conflict of Interest Form Conflict of Interest Pediatric Radiology.docx 


\section{Click here to access/download \\ Conflict of Interest Form COI_article.pdf}




\section{Answers to the comments of the Editor:}

Thanks to the editor for the interest on our paper and for the comments. Below is a point-by-point response to the comments provided

1. I thank you for a very well executed revision. I think the article now is excellently readable and interesting. Only some minor comments as follows.

2. The figure are pixelated. They should be re-exported from source, either as loss-less vector graphics (e.g. pdf) or else as tiff with at least 8,000 pixels' width.

Figures have been formatted accordingly

3. The lines remain too thin and fonts too small. Before submitting, please check how the figures would look at final size. Keep in mind they will appear smaller in the article.

Figures' lines have been modified

4. Fig 1: 'Exclusion criterion' should be 'Exclusion criteria'

Figure 1 has been modified

5. Figs 2, 3: Decimal point should be '.' not ','

Figures 2 and 3 have been modified

6. It may be helpful to the reader if you expand the figure legends slightly to explain what the figures demonstrate?

Figures' legends have been changed:

Figure 1: Preferred Reporting Items for Systematic Reviews and Meta-Analyses flow diagram of search, selection and inclusion of relevant studies

Figure 2: Odds ratio (OR) of leukemia risk following prenatal medical diagnostic X-ray exposure

Figure 3: Odds ratio (OR) of brain tumors risk following prenatal medical diagnostic $\mathrm{X}$-ray exposure

Figure 4: Excess relative risk (ERR) of leukemia risk following postnatal medical diagnostic exposure to computed tomography scan

Figure 5: Excess relative risk (ERR) of brain tumors risk following postnatal medical diagnostic exposure to computed tomography scan

7. The enrolled/exposed columns do not seem to lead to the number in the OR columns of the tables. I 
suppose because some studies looked at several different outcomes? Please can you add an explanation? Thank

As noted by the editor, the "Enrolled subject/Exposed" column in table 1 did not seem to lead readily to the OR reported because some studies considered various outcomes e.g. All cancer, leukemia, Iymphoma, brain tumors etc., in that case the size reported in the "enrolled subject/Exposed" column is that for all cancer combined. In addition, since these studies are case controls, they accounted for major confounding factors and matched at least on factors such as age, sex, and geographic area. And the OR presented are yet the adjusted values on these variables, which are slightly different from the crude value. We modified the legend of the table accordingly.

"\$ Value reported in the "Enrolled subject/Exposed" column is that for all cancer combined or that for the given cancer reported"

"§ Adjusted Odds Ratio or Hazard Ratio (value adjusted on at least age, sex and geographic area)" 